\title{
Moving on: Multiple Transitions of Unaccompanied Child Migrants Leaving Care in England and Sweden
}

\author{
Helen M Roberts ${ }^{1}$, Hannah Bradby ${ }^{2}$, Anne Ingold ${ }^{3}$, Grazia Manzotti ${ }^{4}$, David Reeves ${ }^{4}$, Kristin Liabo $^{5}$ \\ ${ }^{1}$ UCL Great Ormond Street Institute of Child Health, London, UK \\ ${ }^{2}$ Department of Sociology, Uppsala University, Sweden \\ ${ }^{3}$ Hertfordshire, UK \\ ${ }^{4}$ UCL Great Ormond Street Institute of Child Health Library, UK \\ ${ }^{5}$ Institute for Health Research, University of Exeter Medical School, UK \\ Correspondence: Helen M Roberts, UCL Great Ormond Street Institute of Child Health, London, UK.
}

Received: July 5, 2017

Accepted: August 14, $2017 \quad$ Available online: August 21,2017

doi:10.11114/ijsss.v5i9.2523

URL: https://doi.org/10.11114/ijsss.v5i9.2523

\begin{abstract}
This paper explores the priorities of young people who arrived in England or Sweden as unaccompanied minors and are leaving the care of the state to transition to adult life. Policy and practice for these young people are themselves in transition in Europe, and we aim to contribute to the slender first person qualitative evidence base for those delivering services. Our methods comprised a scoping review of scholarly and grey literature, and group and indi vidual interviews. Despite a commitment in both countries to listening to the voices of young people, we identified few studies representing the voices of unaccompanied care leavers. In both the literature and our interviews, health in a clinical sense was rarely among their priorities. Their accounts focused on the determinants of health, and in particular housing, education, food and employment. In Sweden, where services are universal rather than targeted, the Health and Social Care Board (Socialstyrelsen) notes the paradox of unaccompanied children being surrounded by adult supporters, none of whom takes overall responsibility for the young person and his/her everyday life. Those we spoke to describe the vital role played by foster carers, health and social care professionals and friends that they could rely on. The young people whose narratives appear in the research literature and those in our own sample are working hard to cope with multiple transitions and to manage health in its widest sense, whether by finding the right place to live or attending to their education or training.
\end{abstract}

Keywords: unaccompanied asylum seeking children, care system, qualitative, scoping review, Sweden, UK, voice

\section{Introduction}

The UK and Sweden both have a history of providing refuge to those fleeing war, persecution or other dangers. This includes children travelling alone. This is an important population for several reasons. Deprived of their families and in a new culture, often after hazardous journeys they are exposed to loneliness, isolation and exploitation.

This study focuses on children and young people who arrived as unaccompanied minors, entered the care system, and at the time of the interviews were transitioning out of the care system to independence. In discussion with the young people, the ethics committee and the local authority 'gatekeepers' we agreed to keep identifying material to a minimum.

In both the $\mathrm{UK}^{1}$ and Sweden unaccompanied asylum seeking children (UASC) are those under the age of 18 who arrive in a country seeking asylum and without a parent or other responsible adult to take care of them. In both countries, these children and young people enter the care of the state until they reach adulthood. Children in care are those who are looked after by the state. This equates to the term 'foster care' in the USA - but in the UK 'foster care' is used only when children are placed in family homes, and 'residential care' refers to institutions, so 'in care' is the common denominator. 'Care leavers' is not a familiar category in Sweden but $4-5 \%$ of adults are estimated to have experienced out of home care, with large local variations (Vinnerljung 1996). Although universal provision in Nordic welfare

\footnotetext{
${ }^{1}$ https://www.gov.uk/government/uploads/system/uploads/attachment_data/file/561388/UASC_Funding_Instructions_ 2016-17_version_3.pdf
} 
systems reduces stigma, a consequence of universal provision means that there may be little specialist service provision for looked after children and care leavers (Vinnerljung et al 2006).

These children may come from anywhere in the world but the main unaccompanied entrants to the UK are currently from Iraq, Iran and Pakistan. There were 3,680 asylum applications from UASC in the year ending March 2015, a 9\% increase compared to the previous year $(3,389)$. Sweden has offered asylum to significant numbers of refugees over a long period of time. Of the nearly 163,000 asylum applications made in Sweden in 2015, 35,369 were unaccompanied and separated asylum-seeking children - 66\% of whom were Afghani._The 35,369 unaccompanied and separated asylum-seeking children accepted in 2015 is more than 5 times the number accepted in $2014^{2}$. Since November 2015 migration policy has become less open to refugees. The majority of UASC in both England and Sweden are young men, though when families arrive together, as has been the case with those fleeing Syria, girls and boys are more evenly represented. ${ }^{3}$ Conflict in the Middle East and famine are major contributors to the flow of refugees.

In 2015, our research group carried out a participatory study of young people moving out of the care system in an inner city local authority (Liabo, McKenna, Ingold, \& Roberts, 2016). In the course of this study, it was evident that unaccompanied asylum seeking children (UASC) transitioning out of care faced particular challenges. In this light, we returned in 2016 to some of the young people who had arrived unaccompanied. We included Sweden in this phase of the work because of their proud history of welcoming refugees and their record of fewer health inequalities. This study was not, however, a direct comparison between the two.

Guidelines suggest that young people moving from children's to adults' services should be at the heart of decisions about their care. ${ }^{4}$ But even in a climate professing to listen to the voices of service users, we continue to know relatively little about problems and solutions from their point of view. Compared to non-looked after young people, the transition to independent living and adult health services and social care of looked-after children is compressed (Barn, Andrew, \& Mantovani, 2005; McDonagh \& Viner, 2006; Stein, 2004, 2012). Here we report their views supplemented with a scoping study of 'voice' literature from the UK and Sweden. History has often given voice to the more privileged through diaries, biographies, account books and land registries. Thus, the more powerful are more likely to make (or leave) their mark than the young, girls and women, minority ethnic groups, disabled and particularly learning disabled people and those who are poor. Seeking first hand accounts from individuals and communities in these situations represents an opportunity for policy makers to recognize and hear other voices.

\section{What We Already Know (UK):}

Unaccompanied asylum seekers who are in care as minors approach adulthood in difficult circumstances in the face of possible deportation (Wade, Sirriyeeh, Kohli, \& Simmonds, 2012). Our 2015 work found health as traditionally conceived was rarely at the top of young people's agenda, even for those with serious or chronic health problems. Housing, friendships, financial support and education were prioritised. We know that there are high levels of unmet mental health need and that transitions are negatively affected by asylum claims (Chase, Knight, \& Statham, 2008; Wade et al., 2012). Whilst family-based care can provide a solid start in a new country, only a minority of unaccompanied young people experience foster care or do so for only a short period. Most move on to private shared housing (Wade et al., 2012) and when the time comes, the move to independence can be lonely (Chase et al., 2008).

\section{What We Already Know (Sweden):}

'Care leaver' is an unfamiliar categorisation in Sweden and it is an open question whether studies of what is known in Sweden as 'out of home care' can be extrapolated to the subset of UASC. The literature and our discussions with Swedish colleagues indicate that a number of aspects of the care system in general have implications for UASC. Although universal provision in Nordic welfare systems reduces stigma, one consequence is little specialist service provision for looked after children and care leavers (Vinnerljung, Hjern, \& Lindblad, 2006). Sub-optimal contact between health and social services (Kling, Vinnerljung, \& Hjern, 2016) and gaps in knowledge about the health of looked after children (FORTE:, 2015) have been attributed to a lack of systematic procedures for assessing and monitoring the health of children who experience out of home care (Kling et al., 2016). Former care residents are a high-risk group for mental health problems (Vinnerljung \& Hjern, 2014).

\footnotetext{
${ }^{2}$ http://www.migrationsverket.se/Om-Migrationsverket/Nyhetsarkiv/Nyhetsarkiv-2016/2016-01-01-Nastan-163-000-ma nniskor-sokte-asyl-i-Sverige-2015.html

${ }^{3}$ https://www.gov.uk/go vernment/publications/immigration-statistics-january-to-march-2017/how-many-people-do-we-g rant-asylum-or-protection-to
} 


\section{Methods}

We carried out a scoping review (Arai, Stapley, \& Roberts, 2014; Arksey \& O'Malley, 2005) to identify unaccompanied asylum seeking children's own health priorities, searching for qualitative first person 'voice' literature in both English and Swedish. The voices of disenfranchised people are frequently muted in research, 'translated' by professionals or researchers, or used to support a particular case rather than general illumination.

Our searches were informed by KL whose scholarly work is on participation, and who worked as an analyst for a NICE guideline on transition; HB who had recently completed work for WHO on asylum seekers and refugees (Bradby, Humphris, Newall, \& Phillimore, 2015), and HR whose methodological interest are reviews and their usefulness or otherwise to policy makers (Petticrew \& Roberts, 2006; Petticrew \& Roberts, 2008). GM and DR advised us and carried out searches of both scholarly and the grey literature. Abstracts were screened by at least two of us. In the light of our hope that even faintly promising abstracts might yield young peoples' voices in the full texts, HR and HB scanned a large number of these. We found the grey literature to be the most productive.

For the primary 'voice' work, we recruited via a participation and leaving care service in an inner city English borough. In the first part of our study, of the 24 young people who came to at least one meeting or interview, 11 were unaccompanied asylum seekers. Eight were young men, 3 young women aged 17-24. We interviewed 6 of them, three young men, and three young women on an indi vidual basis the following year and also draw on a single interview in Sweden conducted in 2012.

Our recruitment methods included a number of stages to the consent process, including initial interest being canvassed by project workers before we approached the young people with further information and formal consent procedures. Interviews took place in a comfortable private space in a location with which they were familiar and where assistance was nearby had any problems or concerns arisen. The interviews were recorded (with consent) took around an hour, and were sent for transcription and anonymized. The analysis involved HR, HB, AI and KL

Our findings combine the literature and interviews ${ }^{5}$.

\section{Findings}

Most of the literature referred to below was identified through hand searching, following up citations and contacting authors. Books, which remain the publication of choice in the social sciences but do not come up in routine searches, were helpful. Much of the literature we draw on is not specific to UASC, but relates to care leavers more generally. And since we found even fewer 'voice' studies referring to Sweden, compared with the UK, we include some examples of Swedish qualitative literature from refugee children arriving with families, and from young adults who arrived as refugees.

\section{The UK Literature and Our Interviews}

Children seeking asylum in the UK have described being treated with suspicion by immigration officials, a process that may lead to healthcare problems remaining undisclosed (National Children's Bureau, 2006: 9). Young people's accounts show them coping alone in a way which would not normally be tolerated for young people, in or out of care (Chamberlain, Gledhill, McBye, \& Millar, 2005).

\section{Someone Who Cares}

Accounts of accessing healthcare usually featured a supportive carer or professional:

$$
\text { She will even remind me "do this, do that", yeah. }
$$

A young man described the health effects of moving out of foster care at 16:

moving out from a foster placement to an independent place ... did affect my health as there was less sleeping... I think that affects your health ... At the foster family, there's ready meal, they cook for you, whereas there you have to manage yourself, and I wasn't as good a cook as my foster parent...

While a young woman had the opposite problem, feeling that her foster placement never constituted a home:

I always have that in my head "this is not your home, this is not your home" ... I can't have my own keys ... when I'm going to college and I'm coming back to, if she's not home I have to stay outside and wait ...

\footnotetext{
${ }^{5}$ Given the specific concerns they had about their futures and confidentiality, we provide no identifying details in these interviews, but all their voices are used in this paper.
} 


\section{Health Services and Being Listened to:}

In their overview of the extent to which children and young people are consulted on health issues and services, LaValle et al like us, struggled to find care leavers' own accounts (LaValle, Payne, Gibb, \& Jelicic, 2012). They report a study where young people felt that they had not been listened to by clinicians and experienced delays in being seen. Where there were positive views, these were associated with accessible services and understanding staff (Cameron, 2007). This resonated with our interviews where young people reported difficulties registering with a doctor, and once they did, referred to GPs failing to listen, and to seeing a different GP on every visit. This was important since having to tell and retell one's story was described by a number of our interviewees as difficult. A young person told us of the importance of staying with the same GP:

Ifeel so blessed because like trying to go, have to get used to another GP and trying to register all over again and just, yeah ...

Even so, support for mental distress was only sometimes available, even when problems were acute. One young man spoke of the crippling effect of having to repeatedly tell his story to staff in the same hospital and gave this as the reason for declining further Child and Adolescent Mental Health Service (CAMHS) treatment.

A need for mental health services is reiterated in a number of reports (Brady, 2014; LaValle et al., 2012). Along with sexual health services, these are often described as inadequate (Dobel-Ober, 2005; Madge, 2006). However, there may be a perceived stigma for young people referred to or offered mental health services if they are from societies where only the most florid mental health problems come to professional attention (Chase et al., 2008).

A young man we interviewed had refused medical help which would have involved an intimate examination. A young woman described her distress when having an internal examination:

I was like ... "I can't ... no, no, no" and she was saying "you have to do it" ... like she was trying to force me ... and she was... like saying "you need to stop being dramatic ...". And then ... my foster mum was really angry... "you don't need to speak with her like that, you need to, you need to understand why she doesn't want to do that ... you're supposed to be there for them".

One of our interviewees suggested that care leavers should have this status highlighted on medical records, but others were more cautious, feeling that the 'looked after' label carried a stigma. Others worried that information might be used against them, with one young man telling us that his dentist had said by the way your teeth doesn't look as if you are 17 resonating with work from Sweden where any encounter with healthcare providers could be experienced as a test of the right to residency (Jonzon, Lindkvist, \& Johansson, 2015).

For another:

a good [health] service would be someone to attend to the young person quickly and try to sort the problem and not to judge.

One felt that 18 was just too young to be able to negotiate healthcare:

I always think like ... to be a proper adult should be around from 20

Care leavers described problems of motivation and organization. Although they wanted things to happen quickly when they needed health care, they also described missing appointments that no longer seemed urgent to them. A young woman with complex chronic health problems told us:

I have to control my weight ... And I always try to go to gym but... I do feel pain because it's winter... everywhere is dark and I do feel scared. ... because when it's 4:30 or 4 o'clock ... going to gym is kind of really, really hard ....She knows what she ought to do, but the pain she feels, the dark and the cold are too much to overcome. When interviewed the previous year, her focus had been on getting help to pass her exams. By the second interview she seemed unhappy, and less warm towards the foster carer she had spoken of appreciatively the previous year. Exercise was not only important to these young people for the health benefits, but also to alleviate boredom and keep depression at bay:

\section{... one thing Inoticed with exercise, it keeps balance and it fixed my mood as well}

In common with other young people, care leavers or not, even the most capable could find it hard to explain their health needs. Professionals who were impatient with young people's uncertainties or distress were remembered in detail, but so too were those who went the extra mile. For one seventeen year old, turning eighteen meant re-making her relationships with new adult service providers, which she dreaded because of the need to repeat her story. A young man who had transitioned to adult services and needed orthopaedic treatment in order to achieve his modest career ambition did not feel able to talk about this with professionals. Healthcare would often only be sought in response to an acute 
episode.

\section{Education as a Priority}

Health priorities identified by young people in the literature and in our interviews were more frequently about the determinants of health than about access to clinical care or health services:

my teacher keeps saying I'm doing well but ... I'm not doing well ... it's kind of stress-y and giving me like nightmare ... I can 't do it, it make me feel ... that maybe I'm not good enough.

In the absence of a health crisis, both the literature and our interviews identified education and getting a job as more pressing than health care:

I've applied for health and social care BTEC [post-school qualification] .. but I don't think I'm ready for [exams] now because ... I need to have more education background before I can go for that. ...

Education is explained as key to long-term health and wellbeing:

if I'm in charge ... I'll always support in the education ... If you have to draw a pathway education should come first like ...

For one young woman education was a priority not just for her to feel better and do better, but to repay the investment her new country had made in her:

Education should be the first thing in life ...because if they really help them in this education ... the young people has got to pay them back in future

\section{Motivation Exercise and Food}

Food was also a priority for almost all the UASC care leavers we met, as it was in the literature, not just in terms of re-fuelling but in terms of memories:

\section{I really feel like welcome, like I can go in the kitchen, I can cook, anytime I want to cook my countryfood}

\section{Longing and Loss}

A WHO report on refugees and asylum seekers (Bradby et al., 2015) noted that children and young people are frequently assumed to have similar needs to adults. Also noted was a lack of research asking for their own views on health (Papadopoulos, Lees, Lay, \& Gebrehiwot, 2004).

A young woman described thinking of her sister every day, not knowing where she is; a young man talked of his mother, his misery that he did not know where she was. The only asylum seeker we interviewed who spoke explicitly of the effect of waiting for leave to remain told us that his uncertain status prevents him from applying for college. He finds it difficult to tell his story to health professionals - doing so, he says, turns his life into a script. After he had swallowed pills in a serious episode of self-harm, another young man in the same care home insisted he go to hospital and took him there. He spoke of feeling safe in hospital but expressed fears that "loads are coming in," underlining how uncertain life felt for him.

Several UASC told us of the importance to them of faith. A young person doing voluntary work told us:

I like to look Muslim, dress like a Muslim, but I'm just scared what, how would Ibe treated on buses or trains.

His fear underlines a wider problem faced by UASC, whether Muslim or Christian, about the acceptability of observing their religion.

\section{The Swedish Literature}

Notwithstanding a context in which young people in out-of-home care have a higher risk of early mortality, mental health problems, are more likely to commit suicide (Vinnerljung et al., 2006) and have lower educational attainment (Vinnerljung, Berlin, \& Hjern, 2010), we identified few studies specifically focussed on asylum seekers' own accounts of their health priorities. Despite a long tradition of upholding the rights of children and the role this plays in national identity (Bak \& von Brömssen, 2013), the views of children and young people in inspections of the Swedish residential care system are limited (Pålsson, 2015). Such first hand accounts as exist, have commonly focussed on pre-care experiences (Wernesjo, 2012) with an assumption that the journey and its antecedents are the cause of trauma (Bradby et al., 2015).

There are some exceptions. A doctoral thesis provides first hand accounts:

to suddenly arrive in a new country, to live all by yourself ... I had never before been apart from my family. The first day was tough. I had gotten a room all by myself. After a month, I started school ... I felt very lonely... But I met two boys that Imade friends with. (Stretmo, 2014: 232) 
A young woman in the same study regretted the loss of life outside the home:

...it's really difficult to adapt here. In Sweden, everything is kind of, everybody sits inside, like no fun. We who come from other countries, we think it is empty ..nobody is talking, nobody's outside. Everybody goes to bed early. (Stretmo, 2014:236)

For those in residential settings, the difficulty of establishing social contact especially with Swedish peers gave rise to isolation for unaccompanied boys. Once they left care, they said that their migration experiences were linked to feelings of difference and a lack of 'belongingness' (Söderqvist, 2013).

Unaccompanied minors are a highly visible political category and the asylum process is a source of anxiety: it almost made me mentally ill (Lundberg \& Dahlqust, 2012: 63). Others fall ill once their applications are rejected. Despite satisfaction with health care, their situation as asylum seeking children, and their unpredictable futures were worrying and commonly linked to symptoms such as stomach ache and difficulty sleeping (Lundberg \& Dahlqust, 2012). Their accounts included concerns about being economically marginalized, split up as a family and uncertainty about the future (Ascher \& Mellander, 2010: 242). Those whose asylum claims were being processed reported that a residence permit and access to supportive friends and adults in everyday life were prerequisite for health and that everyday conversations were important for general well-being (Lundberg \& Dahlqust, 2012).

The difficulty of being in good health while one's life circumstances are uncertain was illustrated by a fifteen-year-old Afghani who reported being tired and unable to sleep at night with pain throughout his body. His happiness 'goes up and down,' although he was always happy in Afghanistan. When asked 'Are you healthy' he replied 'I don't know' (Backlund, Eriksson, von Greiff, \& Åkerlund, 2012: 48).

Mentoring from the legal guardian for unaccompanied children arriving in Sweden was appreciated:

... It is good to have someone to speak to. For others the system offered no support There is no one who can help you-you have to help yourself (Thommessen, Corcoran, \& Todd, 2015).

Experiences of the Swedish care system are highly dependent on individual relationships, since guardians and professionals vary in how they interpret and carry out their roles (UNHCR, 2010). But even with the best guardian, it is difficult to replace a parent's care. One asylum seeker explained, he only felt better after phoning his mother who lived outside Sweden:

Even if you talk to a psychologist ... it is not the same. ... I wanted mum ... so I could get rid of all the baggage I was carrying, all these thoughts.... (Rosenberg, Bolin, \& Drejare, 2012: 39)

Jonzon et al in their study of adult migrants, report views also likely to apply to young people which is a concern that the underlying purpose of any professional contact could be to assess an asylum claim.

I went to the health center and it was like an interrogation... "When did you come to Sweden? Why did you come here?" ... It was the same as they asked me at the migration authority.

... if they find something, how will that affect my chance to obtain asylum, and if they find a disease, will they help or what will happen? (Jonzon et al., 2015)

A pan European report (UNHCR \& Europe, 2014) which includes testimonies from young people also refers to uncertainty as a source of dis-ease: It's so stressful, I don't know what to do, Idon't know where I'm going to live.... And in a study of children aged 6 to 18 years, mainly from the middle east and seeking asylum (in this case with their families) a fifteen year old boy described the paradoxical nature of health: You can feel good in your body even though inside you feel poorly. (Man kan må bra i kroppen fastän insidan mår dåligt.) (Vara glad ... inte bara att vara frisk. Det finns saker som påverkar hur man mår (Ascher \& Mellander, 2010:215).

The importance of education was recognised by both Swedish and UK asylum seeking care leavers as key to health:

I'll be turning 21 ... Not knowing where you're gonna go after is a lot of pressure...I really wanted to study, that's what I want to do, but now I will study part-time and work part-time. Education is my number one priority. And they tried to put a lot of barriers to try and stop you [...] It 's not even a transition, you're an adult all of a sudden. (UNHCR \& Europe, 2014)

The family-centred nature of the care system in Sweden means that research on transitions tends to refer to young people living with their families (e.g. (Bjorquist, Nordmark, \& Hallstrom, 2015a, 2015b)). In a context where family-based care is prioritized, the irony of 'losing' a parent once she left her out of home care did not escape this care leaver:

I have lived there for five years, and they have told me 'these people shall be your parents', and all of a sudden I am supposed to be on my own 'now they aren 't your parents anymore'. (Höjer \& Sjöblom, 2010: 123) 


\section{Discussion}

This paper presents evidence from two sources, interviews and 'voice' literature in an attempt to illustrate the problems faced by unaccompanied asylum seeking children and the professionals who care for them. The strength of this paper is that it adds to a slender evidence base at a time when UASC are high on both public and policy agendas; the limitation is that this additional evidence is itself patchy. A further limitation of our data is that the young people we spoke with are (relatively speaking) well-supported. They were recruited from a social services-run participation project co-located with a high quality medical team focused on children in care. That even these 'privileged' young people expressed difficulties, suggests that problems may be more acute elsewhere. Given the overall lack of evidence, our material is worth considering despite these limitations.

Finally we had hoped that looking at differing approaches in the UK and in Sweden, two countries with well-developed welfare systems, might offer some straightforward lessons. The universal system (which avoids stigmatization) in the Nordic countries, and the more targeted system in the UK for particular populations, have both strengths and weaknesses.

Evidence-informed policy and practice recommendations for young people leaving care have been well-rehearsed over the years. One of the fullest accounts remains Young people and leaving care schemes (Biehal, Clayden, \& Stein, 1995) describing and promoting education, housing, employment and training, developing life skills, identity work and relationship building as key to young people's wellbeing. Education is highlighted as a major determinant of health (Burnett \& Peel, 2001) supporting the observation that the most therapeutic event for a refugee child is to become part of the local school community, learn, and make friends (Melzak \& Kasabova, 1999). To this extent, the data presented here, where young people themselves underline the importance of the wide determinants of health for their own wellbeing, is important.

\section{Conclusions}

In common with other young people, care leavers in relatively good health do not have health care as a priority. What is worrying is that the same appears to be true for those with serious health problems, including mental health problems. For those in good general health, ill effects are unlikely to accumulate until later in life (Vinnerljung, Brännström, \& Hjern, 2015; Vinnerljung \& Hjern, 2014; Vinnerljung et al., 2006; Vinnerljung \& Sallnäs, 2008).

Unaccompanied children represent a combination of resilience - in finding ways of living in a new culture without family support - plus vulnerability to despair because of that lack of support. The care the young people we interviewed would have liked for themselves was sometimes evident in the care they gave others in the same situation, or in the case of one young man, people he looked after in a care home:

I saw people who've had such successful lives, teachers, engineers, and they... can't remember anything. They ... don't know their very closest relatives... It's very emotional for me...They worked so hard... and now they are, they're in a care home and ... the saddest part was that it was near Christmas time, and ... the person was like, "I'm not looking forward to it."

Although care leavers who arrive as unaccompanied children may be exceptionally resourceful and mature in some respects, when they come to leave care, they may lack the skills and confidence to talk to doctors and others in authority. The unaccompanied young people we met described the vital role played by foster carers, health and social care professionals and friends. They described having a key worker they could rely on as important, but the availability of personal advisors for one-to-one support is limited. The tenacity required to get things done (or undone) is likely to be more challenging for these young people than for those with conventional family support.

Participation is an important right for unaccompanied children, given that they have to cope with moving in with strangers, meeting professionals in formal situations and dealing with discrimination (Chamberlain et al., 2005). Those who provide services are all too well aware of the problem of how to turn the compelling evidence of what is needed at the level of the individual into policy-level or practice solutions:

How can we be as close as we can be to what the experiences of a young person living and, being brought up in a birth family are ? ... I think it's very hard for a local authority to mimic (Roberts, McKenna, Ingold, \& Liabo, 2015)

The opening remark in a classic leaving care study is: 'When you come out of care, it's hell ... You don't know about what you're doing or where you're going. It's just like taking you from one country and putting you into another.' (Biehal et al., 1995: 3). The young people in our study are literally moving from one country to another. Our primary and secondary qualitative data illustrate the pain, triumphs, hopes and fears of these frontline experts - and a near universal attempt to provide a narrative of themselves as resilient winners.

\section{Acknowledgements}


We are grateful for the time and commitment of the young people we interviewed, and the advice and support of colleagues in the participation, leaving care, and Children Looked After health service in the area where the study was carried out. In order to maintain the confidentiality of professionals and young people interviewed, and on the advice of the service which was our gateway to recruitment, this acknowledgement is heartfelt, but at the request of our main gatekeepers, we do not name individuals and we have used no names or other identifying features for the young people we interviewed. We are also grateful to Dr Rachel Knowles for agreeing to act as a contact person had any of our participants wanted to complain (no one did); Dr Thomas Lewis in the Great Ormond Street/UCL Institute of Child Health R\&D office and Mrs Barbara Cuddon at the Social Care Ethics Committee. Dr Chloe Parkin provided valuable assistance in assuring the progress of the work. We are grateful for comments and suggestions from members of the Welfare and Life course Research Group at the University of Uppsala, Sweden and especially Professor Rafael Lindqvist. We benefitted from helpful information from Dr Martin Molin of University West, Dr Charlotte Melander of Gothenberg University and Professor Bo Vinnerljung of Stockholm University.

The Policy Research Unit in the Health of Children, Young People and Families is funded by the Department of Health Policy Research Programme. The views expressed are not necessarily those of the Department.

This research was also supported by the National Institute for Health Research Biomedical Research Centre at Great Ormond Street Hospital for Children NHS Foundation Trust and University College London.

We would like to thank members of the Policy Research Unit for the Health of Children, Young People and Families: Terence Stephenson, Catherine Law, Amanda Edwards, Ruth Gilbert, Steve Morris, Cathy Street, Russell Viner and Miranda Wolpert.

\section{Ethics}

The study was approved by the HRA Social Care Research Ethics Committee (15/EC08/0009).

\section{References $^{6}$}

Arai, L., Stapley, S., \& Roberts, H. (2014). 'Did not attends' in children 0-10: a scoping review. Child: Care, Health and Development, 40(6), 797-805. https://doi.org/10.1111/cch.12111

Arksey, H., \& O'Malley, L. (2005). Scoping studies: towards a methodological framework. International Journal of Social Research Methodology, 8, 19-32. https://doi.org/10.1080/1364557032000119616

Ascher, H., \& Mellander, L. (2010). Asylsökande barns tankar om hälsa. In H. E. Andersson, H. Asher, U. Björnberg, \& M. Eastmond (Eds.), Mellan det förflutna och framtiden. Asylsökande barns välfärd, hälsa och välbefinnande (pp. 207-243). Göteborg: Göteborgs Universitet, Centrum för Europaforskning.

Backlund, A., Eriksson, R., von Greiff, K., \& Åkerlund, E. -M. (2012). Ensam och flyktingbarn - barnet och socialtjänsten om den första tiden $i$ Sverige. Retrieved from

http://fou-sodertorn.se/wp-content/uploads/2016/09/Rapport-nr-1-2012.pdf

Bak, M., \& von Brömssen, K. (Eds.). (2013). Barndom och migration. Umeå: Borea.

Barn, R., Andrew, L., \& Mantovani, N. (2005). Life after care: The experiences of young people from different ethnic groups. York: Joseph Rowntree Foundation.

Biehal, N., Clayden, J., \& Stein, M. (1995). Moving on: young people and leaving care schemes. Retrieved from London: https://pure.york.ac.uk/portal/en/publications/moving-on-young-people-and-leaving-care-schemes(6c2b6f6f-536e4790-8be9-266227d24645)/export.html

Bjorquist, E., Nordmark, E., \& Hallstrom, I. (2015a). Living in transition - experiences of health and well-being and the needs of adolescents with cerebral palsy. Child Care Health Dev, 41 (2), 258-265.

Bjorquist, E., Nordmark, E., \& Hallstrom, I. (2015b). Parents' Experiences of Health and Needs When Supporting Their Adolescents With Cerebral Palsy During Transition to Adulthood. Phys Occup Ther Pediatr, 1-13.

Bradby, H., Humphris, R., Newall, D., \& Phillimore, J. (2015). Public health aspects of migrant health: a review of the evidence on health status for refugees and asylum seekers in the European Region. Retrieved from Copenhagen: http://www.euro.who.int/__data/assets/pdf_file/0004/289246/WHO-HEN-Report-A5-2-Refugees_FINAL.pdf

Brady, R. (2014). The costs of not caring: supporting English care leavers into independence. Retrieved from Barkingside: http://www.barnardos.org.uk/costs_of_care_leavers.pdf

6 In addition to the references above, a Cochrane evidence aid can be found at: http://www.evidenceaid.org/the-health-of-refugees-and-asylum-seekers-in-europe/ 
Burnett, A., \& Peel, M. (2001). Health needs of asylum seekers and refugees. British Medical Journal, 322(7285), 544-547.

Cameron, C. (2007). Access to health services: Care leavers and young people 'in difficulty'. ChildRight, 238, 22-25.

Chamberlain, C., Gledhill, K., McBye, K., \& Millar, J. (2005). Start with the child. Stay with the child. A Blueprint for a Child-centred Approach to Children and Young People in Public Care. Retrieved from London: http://www.coramvoice.org.uk/sites/default/files/Blueprint main doc.pdf

Chase, E., Knight, A., \& Statham, J. (2008). The emotional well-being of young people seeking asylum in the UK. Retrieved from London: https://corambaaf.org.uk/books/emotional-well-being-young-people-seeking-asylum-uk

Dobel-Ober, D. (2005). The views of looked afteryoung people about health and health care. London: National Children's Bureau.

FORTE:. (2015). Barn och Unga i Samhällets Vård. Forskning om den sociala dygnsvården. Retrieved from http://www.forte.se/fk-vardbarn

Höjer, I., \& Sjöblom, Y. (2010). Young people leaving care in Sweden. Child \& Family Social Work, 15(1), 118-127. https://doi.org/10.1111/j.1365-2206.2009.00661.x

Jonzon, R., Lindkvist, P., \& Johansson, E. (2015). A state of limbo--in transition between two contexts: Health assessments upon arrival in Sweden as perceived by former Eritrean asylum seekers. Scand J Public Health, 43(5), 548-558. https://doi.org/10.1177/1403494815576786

Kling, S., Vinnerljung, B., \& Hjern, A. (2016). Somatic assessments of 120 Swedish children taken into care reveal large unmet health and dental care needs. Acta Paediatr, 105(4), 416-420. https://doi.org/10.1111/apa.13304

LaValle, I., Payne, L., Gibb, J., \& Jelicic, H. (2012). Listening to children's views on health provision. A rapid review of the evidence Retrieved from London:

http://repository.ncb.org.uk/uploads/research/ncb_rsch_summ8_final_for_web.pdf

Liabo, K., McKenna, C., Ingold, A., \& Roberts, H. (2016). Leaving foster or residential care: a participatory study of care leavers' experiences of health and social care transitions. Child Care Health Dev. https://doi.org/10.1111/cch.12426

Lundberg, A., \& Dahlqust, L. (2012). Unaccompanied children seeking asylum in Sweden: living conditions from a child-centred perspective. Refugee Survey Quarterly, 31(2), 54-75. https://doi.org/10.1093/rsq/hds003

Madge, N. (2006). Young people talking about their health and health services. London: National Children's Bureau.

McDonagh, J. E., \& Viner, R. (2006). Lost in transition? Between paediatric and adult services. BMJ, 332(7539), 435-436.

Melzak, S., \& Kasabova, S. (1999). Working with children and adolescents from Kosovo. London: Medical Foundation for the Care of Victims of Torture.

National Children's Bureau. (2006). Supporting young parents who are looked after or leaving care. Retrieved from London:

http://www.scie-socialcareonline.org.uk/supporting-young-parents-who-are-looked-after-or-leaving-care/r/a11G00 0000181QgIAI

Pålsson, D. (2015). Conditioned agency? The role of children in the audit of Swedish residential care. Child \& Family Social Work, 1-10.

Papadopoulos, I., Lees, S., Lay, M., \& Gebrehiwot, A. (2004). Ethiopian refugees in the UK: migration, adaptation and settlement experiences and their relevance to health. Ethn Health, 9(1), 55-73. https://doi.org/10.1080/1355785042000202745

Petticrew, M., \& Roberts, H. (2006). Systematic reviews in the social sciences: a practical guide. Oxford: Blackwells. https://doi.org/10.1002/9780470754887

Petticrew, M., \& Roberts, H. (2008). Systematic reviews--do they 'work' in informing decision-making around health inequalities? Health Econ Policy Law, 3(Pt 2), 197-211.

Roberts, H., McKenna, C., Ingold, A., \& Liabo, K. (2015). Moving on: Transitions for young people using health and social care services London.

Rosenberg, D., Bolin, M., \& Drejare, J. (2012). Som vilket barn som helst. Erfarenheter av 25 års mottagande av ensamkommande flyktingbarn i Härnösand

(Rapport 2012:8). Retrieved from 
http://www.fouvalfard.se/som-vilket-barn-som-helst-erfarenheter-av-25-ars-mottagande-av-ensamkommande-flykt ingbarn-i-harnosand

Söderqvist, Å. (2013). Leaving Care with "Cultural Baggage": The Development of an Identity within a Trans national Space. Australian Social Work, 67(1), 39-54. https://doi.org/10.1080/0312407X.2013.863955

Stein, M. (2004). What works for young people leaving care? Barkingside: Barnardo's.

Stein, M. (2012). Young people leaving care: Supporting pathways to adulthood. London: Jessica Kingsley.

Stretmo, L. (2014). Governing the unaccompanied child - media, policy and practice. (PhD), Göteborgs universitet, Göteborg. Retrieved from https://gupea.ub.gu.se/handle/2077/36106

Thommessen, S. A. O. T., Corcoran, P., \& Todd, B. K. (2015). Experiences of arriving to Sweden as an unaccompanied asylum-seeking minor from Afghanistan: An interpretative phenomenological analysis. Psychology of Violence, 5(4), 374-383. https://doi.org/10.1037/a0038842

UNHCR. (2010). Voices of Afghan children. A study on asylum-seeking children in Sweden. Retrieved from Stockholm: http://www.unhcr.org/4c8e24a16.pdf

UNHCR, \& Europe, C. o. (2014). Unaccompanied and separated asylum-seeking and refugee children turning eighteen: what to celebrate? Retrieved from Strasborg: https://rm.coe.int/unhcr-coereporttransitionadulthood/native/1680724c42

Vinnerljung, B., Berlin, M., \& Hjern, A. (2010). Skolbetyg, utbildning och risker för ogynnsam utveckling hos barn [School performance, educational attainment and risks for unfavorable development in children]. Stockholm: Socialstyrelsen.

Vinnerljung, B., Brännström, L., \& Hjern, A. (2015). Disability pension among adult former child welfare clients: A Swedish national cohort study. Children and Youth Services Review, 56, 169-176. https://doi.org/10.1016/j.childyouth.2015.07.001

Vinnerljung, B., \& Hjern, A. (2014). Consumption of psychotropic drugs among adults who were in societal care during their childhood-A Swedish national cohort study. Nord J Psychiatry, 68(8), 611-619. https://doi.org/10.3109/08039488.2014.902501

Vinnerljung, B., Hjern, A., \& Lindblad, F. (2006). Suicide attempts and severe psychiatric morbidity among former child welfare clients--a national cohort study. $J$ Child Psychol Psychiatry, 47(7), 723-733. https://doi.org/10.1111/j.1469-7610.2005.01530.x

Vinnerljung, B., \& Sallnäs, M. (2008). Into adulthood: a follow-up study of 718 young people who were placed in out-of-home care during their teens. Child \& Family Social Work, 13(2), 144-155. https://doi.org/10.1111/j.1365-2206.2007.00527.x

Wade, J., Sirriyeeh, A., Kohli, R., \& Simmonds, J. (2012). Preparation and transition planning for unaccompanied asylum-seeking and refugee young people: Areview of evidence in England. Children and Youth Services Review, 13, 2424-2430.

Wernesjo, U. (2012). Unaccompanied asylum-seeking children: Whose perspective? Childhood, 19(4), 495-507.

\section{Copyrights}

Copyright for this article is retained by the author(s), with first publication rights granted to the journal.

This is an open-access article distributed under the terms and conditions of the Creative Commons Attribution license which permits unrestricted use, distribution, and reproduction in any medium, provided the original work is properly cited. 